\title{
Effect of Cu or Ti Substitution in MgNi on Crystal Structure and Hydrogen Absorption-Desorption Properties
}

\author{
Yasutaka Kamata, Takahiro Kuriiwa, Atsunori Kamegawa* and Masuo Okada \\ Department of Materials Science, Graduate School of Engineering, Tohoku University, Sendai 980-8579, Japan
}

\begin{abstract}
Our previous study showed the noble $\mathrm{MgNi}$ intermetallic compound with a CuTi-type crystal structure could be synthesized from amorphous $\mathrm{MgNi}$ precursor under more than $5 \mathrm{GPa}$ by high pressure synthesis and could be hydrogenated into novel hydride with a CsCl-type crystal structure at $355 \mathrm{~K}$ under $2 \mathrm{MPa}$ of hydrogen. In this study, hydrogen absorption-desorption properties of the MgNi compound with CuTitype structure were investigated. It was found that the $\mathrm{MgNi}$ with CuTi-type structure absorbed and desorbed hydrogen reversibly at $473 \mathrm{~K}$. Effects of substitution of $\mathrm{Ni}$ by $\mathrm{Cu}$ or $\mathrm{Ti}$ in the $\mathrm{MgNi}$ compounds were also investigated. Ternary $\mathrm{MgNi}_{1-x} \mathrm{Cu}_{x}(x=0.2,0.5)$ and $\mathrm{MgNi}_{0.9} \mathrm{Ti}_{0.1}$ compounds were synthesized from amorphous precursors by high pressure synthesis. $\mathrm{The}_{\mathrm{MgNi}} \mathrm{Cu}_{1-x}(x=0.2,0.5)$ and $\mathrm{MgNi}_{0.9} \mathrm{Ti}_{0.1}$ have CsCl-type crystal structure. The lattice parameter of $\mathrm{MgNi}_{1-x} \mathrm{Cu}_{x}$ increased with increasing of $\mathrm{Cu}$ content. $\mathrm{MgNi}_{1-x} \mathrm{Cu}_{x}(x=0.2,0.5)$ and $\mathrm{MgNi}_{0.9} \mathrm{Ti}_{0.1}$ could be hydrogenated under hydrogen pressure of $2 \mathrm{MPa}$ and the crystal structure of these hydrides were CsCl-type structure. The hydrogen desorption temperature of these hydrides decreased with increasing of amount of $\mathrm{Cu}$ or Ti substitution of Ni. The substitution of Ni by $\mathrm{Ti}$ in $\mathrm{MgNi}$ improved the hydrogen absorption capacity from 1.65 to 2.06 mass\%. [doi:10.2320/matertrans.M2009064]
\end{abstract}

(Received February 17, 2009; Accepted May 18, 2009; Published July 1, 2009)

Keywords: hydrogen storage alloy, high-pressure synthesis, magnesium-nickel intermetallic compound, copper or titanium substitution

\section{Introduction}

High-pressure synthesis is known to be an effective method to explore novel compounds. In the field of developments of hydrogen storage media, many new hydrides have been reported with this technique. High-pressure synthesis can be mainly classified into two groups according to by means of pressure transmitting media, one method is autoclave with gaseous media, the other is anvil-type apparatus with solid media. For example, $\mathrm{CsMgH}_{3},{ }^{1)}$ $\mathrm{LaMg}_{2} \mathrm{H}_{7}{ }^{2)}$ and $\mathrm{CeMg}_{2} \mathrm{H}_{7}{ }^{2)}$ were synthesized under a high pressure of about $10 \mathrm{MPa}$ by using the autoclave apparatus. On the other hand, $\mathrm{Mg}_{3} \mathrm{MnH}_{7}{ }^{3)}$ and $\mathrm{Sr}_{6} \mathrm{Mg}_{7} \mathrm{H}_{26}{ }^{4)}$ and so on, were reported with high pressure up to $\mathrm{GPa}$ order using anvil-type apparatus. We reported that $\left.\mathrm{Mg}_{2} \mathrm{Ni}_{3} \mathrm{H}_{3.4}, 5,6\right)$ $\left.\mathrm{Mg}_{3} \mathrm{MnH}_{\mathrm{y}},{ }^{7)} \mathrm{MgY}_{2} \mathrm{H}_{8},{ }^{7-10)} \mathrm{Mg}_{3} \mathrm{REH}_{9}(\mathrm{RE}=\mathrm{La}, \mathrm{Ce}, \mathrm{Pr}),{ }^{10,11}\right)$ $\mathrm{MgTM}_{2} \mathrm{H}_{\mathrm{y}}(\mathrm{TM}=\mathrm{Zr}, \mathrm{Nb}, \mathrm{Hf}),{ }^{12)} \mathrm{Mg}_{6.2} \mathrm{NbH}_{\mathrm{y}},{ }^{12)} \mathrm{Mg}_{\mathrm{x}} \mathrm{TaH}_{\mathrm{y}},{ }^{12)}$ $\mathrm{Mg}_{3} \mathrm{MoH}_{\mathrm{y}},{ }^{13)} \mathrm{Mg}_{4} \mathrm{NbH}_{\mathrm{y}},{ }^{13)} \mathrm{MgNi}_{2} \mathrm{H}_{\mathrm{y}},{ }^{14,15)} \quad \mathrm{Mg}_{2} \mathrm{LiH}_{\mathrm{y}},{ }^{16)}$ $\mathrm{MgCu},{ }^{17)} \mathrm{Mg}_{54} \mathrm{Cu}_{17}{ }^{17)}$ and $\mathrm{MgNi}_{2}$ of high pressure phase ${ }^{18)}$ were obtained by this apparatus.

Mg-based alloys and their hydrides have been extensively studied because of their promising hydrogen storage capacity as hydrogen storage media. Among Mg-based materials, $\mathrm{Mg}-\mathrm{Ni}$ system has been most widely studied since Reilly firstly reported $\mathrm{Mg}_{2} \mathrm{NiH}_{4}$ as hydrogen storage alloy. ${ }^{19)}$ However, a major shortcoming of the $\mathrm{Mg}$-based hydrides is that those need high operating temperatures, especially for dehydrogenation. There are two intermetallic compounds as equilibrium phases in the $\mathrm{Mg}-\mathrm{Ni}$ binary system, that is, $\mathrm{Mg}_{2} \mathrm{Ni}$ and $\mathrm{MgNi}_{2} .{ }^{20)} \mathrm{MgNi}_{2}$, which have known not to react with hydrogen, ${ }^{19}$ ) was also hydrogenated by high pressure hydrogen up to $2 \mathrm{GPa} .{ }^{14,15)}$ To improve their hydrogenation and dehydrogenation properties, it is important to explore new Mg-based hydrides or intermetallic compounds. Orimo et al. have reported the hydriding properties of amorphous $\mathrm{MgNi}$ and its nano-scaled structure. ${ }^{21)}$ The amorphous MgNi

*Corresponding author, E-mail: kamegawa@material.tohoku.ac.jp was hydrogenated by mechanical grinding under hydrogen atmosphere of $1 \mathrm{MPa}$ and the hydrogen content was 2.2 mass $\% .^{21)}$

On the other hand, we reported that $\mathrm{MgNi}$ with CuTi-type structure was synthesized from amorphous $\mathrm{MgNi}$ precursor by high-pressure synthesis. ${ }^{22)}$ The crystalline $\mathrm{MgNi}$ of high pressure phase with CuTi-type crystal structure was hydrogenated into novel hydride with CsCl-type structure in metal sub-lattice at $355 \mathrm{~K}$ under hydrogen pressure of $2 \mathrm{MPa}$ and the hydride was decomposed into $\mathrm{Mg}_{2} \mathrm{Ni}$ and $\mathrm{MgNi}_{2}$ up to $623 \mathrm{~K}$ under an $\mathrm{Ar}$ atmosphere. ${ }^{22)}$

Recently, it was revealed that the $\mathrm{MgNi}$ hydride desorbed hydrogen returned to the CuTi-type structure crystal at the lower temperature of $473 \mathrm{~K}$. So there is a possibility that the $\mathrm{MgNi}$ absorbs and desorbs hydrogen reversibly.

The purpose of the present work is to investigate reversible hydrogen absorption-desorption properties of $\mathrm{MgNi}$, and to study the effect of $\mathrm{Cu}$ or $\mathrm{Ti}$ addition to $\mathrm{MgNi}$ on their crystal structure and hydrogen absorption-desorption properties.

\section{Experimental Procedures}

The starting materials were $\mathrm{Mg}$ (99.9 mass\%), Ti (99 mass\%), $\mathrm{Ni}(99.9$ mass\%) and $\mathrm{Cu}(99.9$ mass \%) powders. Amorphous $\mathrm{MgNi}, \quad \mathrm{MgNi}_{1-x} \mathrm{Cu}_{x} \quad(x=0.2,0.5) \quad$ and $\mathrm{MgNi}_{1-x} \mathrm{Ti}_{x}(x=0.1)$ were used as precursors, which were prepared by mechanical alloying for $80 \mathrm{~h}$ with rotation speed of $300 \mathrm{rpm}$ from $\mathrm{Ni}, \mathrm{Ti}, \mathrm{Cu}$ and $\mathrm{Mg}_{2} \mathrm{Ni}$ powders. $\mathrm{Mg}_{2} \mathrm{Ni}$ was prepared by sintering at $803 \mathrm{~K}$ for $5 \mathrm{~h}$ under $\mathrm{Ar}-3 \mathrm{~mol} \% \mathrm{H}_{2}$ atmosphere from mixture of $\mathrm{Mg}$ and $\mathrm{Ni}$ powders. Then, amorphous precursor was pressed into pellet. The pellet was put into a BN container. The container was then put into a graphite tube heater, and placed into a pressure media made from pyrophyllite. All the manipulations of sample preparations were conducted in a glove box filled with an Ar gas. The sample was placed into the anvil-type apparatus and then high-pressure synthesis was carried out with it. Samples were heated at $523-623 \mathrm{~K}$ for $2 \mathrm{~h}$ under $6 \mathrm{GPa}$ and then quenched 
into ambient temperature and pressure. Phase identification was carried out by X-ray diffractometry (XRD). Then, lattice parameters were refined by $\mathrm{CELL}^{23)}$ program. Thermal stability of the samples was measured by differential scanning calorimeter (DSC) under an Ar atmosphere. Hydrogenation of the samples was also performed by DSC under hydrogen pressure of $2 \mathrm{MPa}$. The thermal gas desorption properties were examined by thermal desorption mass spectroscopy (TDMS) combined with thermogravimetry (TG) and differential thermal analysis (DTA). The pressure composition isotherms (PCT curves) were measured by using Sieverts-type apparatus.

\section{Results and Discussion}

Figure 1 shows XRD patterns of MgNi prepared at $623 \mathrm{~K}$ for $2 \mathrm{~h}$ under $6 \mathrm{GPa}$, and the sample after hydrogenation of $\mathrm{MgNi}$ and after dehydrogenation of the $\mathrm{MgNi}$ hydride. $\mathrm{MgNi}$ hydride with CsCl-type structure in metal sub-lattice desorbed hydrogen and returned to $\mathrm{MgNi}$ compound with CuTi-type crystal structure by heating up to $473 \mathrm{~K}$ although a small amount of $\mathrm{Mg}_{2} \mathrm{Ni}$ was observed. The results of X-ray diffraction confirmed that the crystal structure of $\mathrm{MgNi}$ desorbed hydrogen was same as that before absorption of hydrogen. To investigate hydrogen absorption-desorption properties of MgNi compound, PCT curves were measured. Figure 2 shows PCT curves of MgNi compound synthesized by high-pressure at $423-473 \mathrm{~K}$. The low-pressure hydrogen uptake of $\mathrm{MgNi}$ with CuTi-type structure occurred under pressure of hydrogen less than $0.2 \mathrm{MPa}$ and further hydrogen

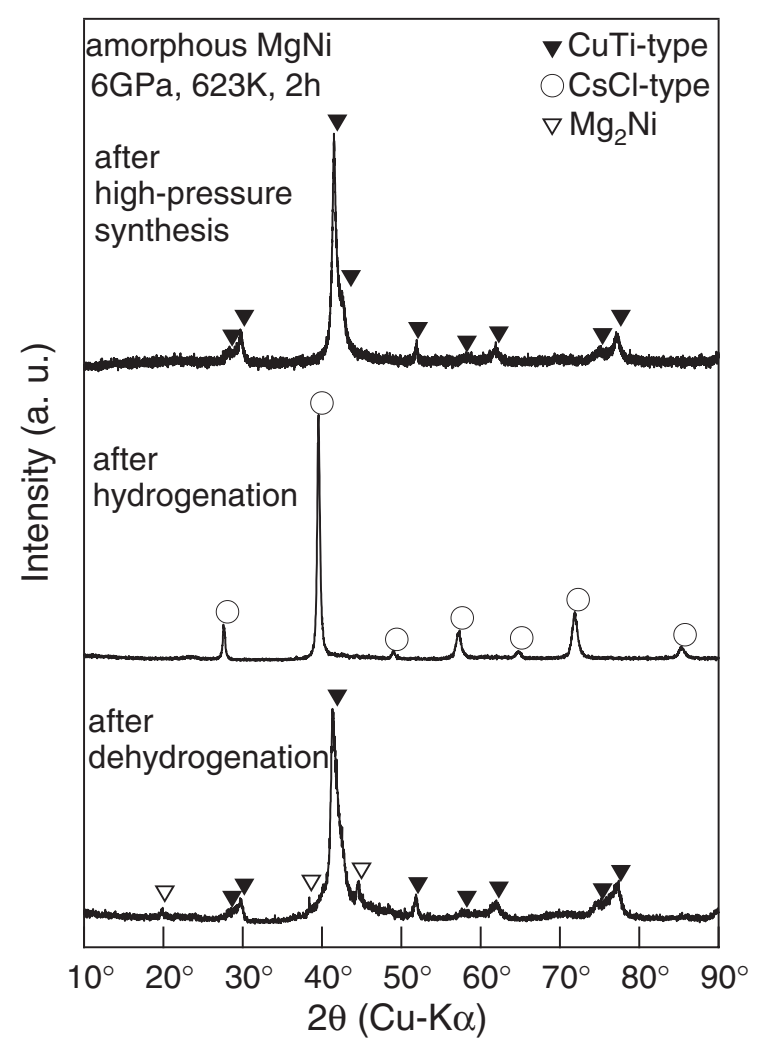

Fig. 1 XRD patterns of high-pressure synthesized $\mathrm{MgNi}$ samples as synthesized, after hydrogenation and after dehydrogenation.

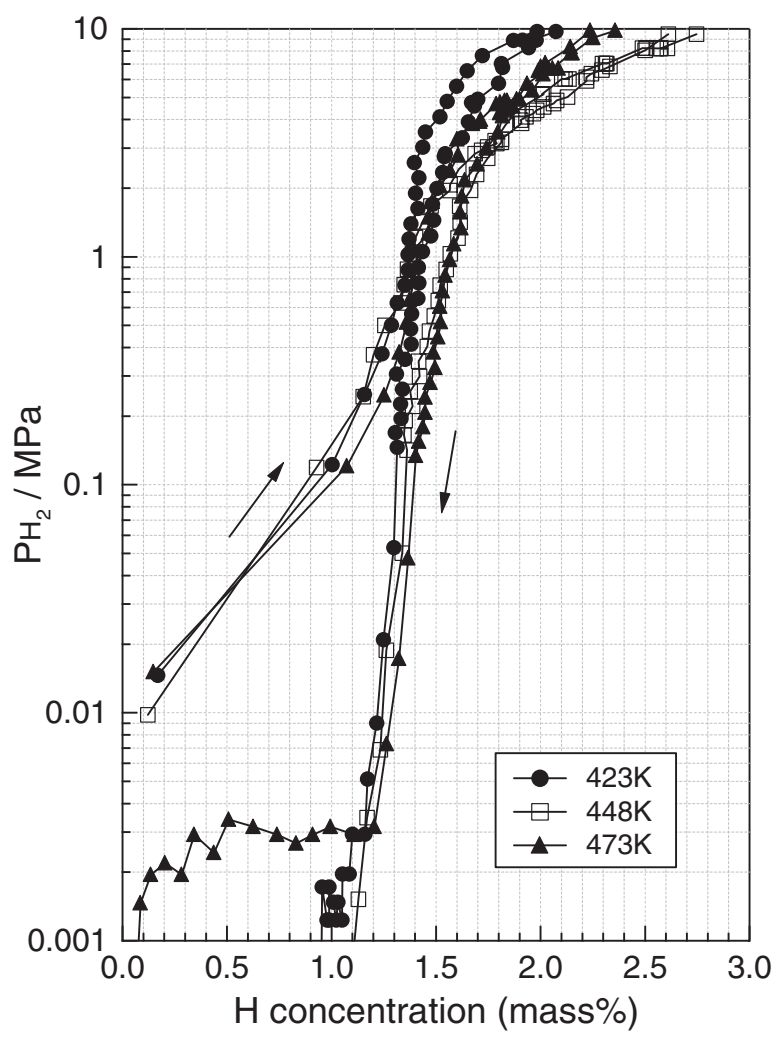

Fig. 2 PCT curves of MgNi synthesized by high-pressure at 423-473 K.

absorption took place under pressure of hydrogen more than $3 \mathrm{MPa}$. The $\mathrm{MgNi}$ absorbed 2.75 mass\% $(\mathrm{H} / \mathrm{M}=1.13)$ of hydrogen at $448 \mathrm{~K}$ at hydrogen pressure of $10 \mathrm{MPa}$, but amount of desorbed hydrogen was smaller than that of absorbed at a temperature below $448 \mathrm{~K}$. However $\mathrm{MgNi}$ desorbed almost hydrogen at $473 \mathrm{~K}$. Thus, it could be said that the $\mathrm{MgNi}$ absorbed and desorbed hydrogen reversibly at $473 \mathrm{~K}$.

Figure 3 shows XRD patterns of $\mathrm{MgNi}_{1-x} \mathrm{Cu}_{x} \quad(x=$ $0.0,0.2,0.5)$ prepared from amorphous precursors at $623 \mathrm{~K}$ or $573 \mathrm{~K}$ for $2 \mathrm{~h}$ under $6 \mathrm{GPa} . \mathrm{MgNi}_{0.8} \mathrm{Cu}_{0.2}$ and $\mathrm{MgNi}_{0.5} \mathrm{Cu}_{0.5}$ were synthesized as single phases at $573 \mathrm{~K}$ while $\mathrm{MgNi}$ was synthesized as a single phase at $623 \mathrm{~K}$. The crystal structure of $\mathrm{MgNi}_{1-x} \mathrm{Cu}_{x}(x=0.2,0.5)$ was CsCl-type structure which differed from that of $\mathrm{MgNi}$ of CuTi-type and the lattice parameter of the samples increases with increasing of $\mathrm{Cu}$ content. Figure 4 shows DSC curves of the $\mathrm{MgNi}_{1-x} \mathrm{Cu}_{x}$ $(x=0.0,0.2,0.5)$. Two exothermic peaks were observed for $\mathrm{MgNi}$ and $\mathrm{MgNi}_{0.8} \mathrm{Cu}_{0.2}$. The exothermic peak of $\mathrm{MgNi}$ of low temperature corresponds to the decomposition of $\mathrm{MgNi}$ of high-pressure phase into $\mathrm{Mg}_{2} \mathrm{Ni}$ and amorphous phases. ${ }^{22)} \mathrm{MgNi}_{0.8} \mathrm{Cu}_{0.2}$ may also decompose into $\mathrm{Mg}_{2} \mathrm{Ni}$ phase and amorphous phase during first exothermic reaction. The decomposition temperature of $\mathrm{MgNi}_{1-x} \mathrm{Cu}_{x} \quad(x=0.0$, $0.2,0.5)$ decreased with increasing of $\mathrm{Cu}$ content. This result is similar to behavior of reported amorphous $\mathrm{MgNi}_{1-x} \mathrm{Cu}_{x}{ }^{24)}$ Orimo et al. reported that the crystallization temperature into $\mathrm{Mg}_{2} \mathrm{Ni}$ and $\mathrm{MgNi}_{2}$ of amorphous $\mathrm{MgNi}_{1-x} \mathrm{Cu}_{x}$ linearly decrease with increasing of $\mathrm{Cu}$ content. ${ }^{24)}$

To investigate hydrogenation properties of the $\mathrm{MgNi}_{1-x} \mathrm{Cu}_{x} \quad(x=0.0,0.2,0.5)$, DSC measurement was 


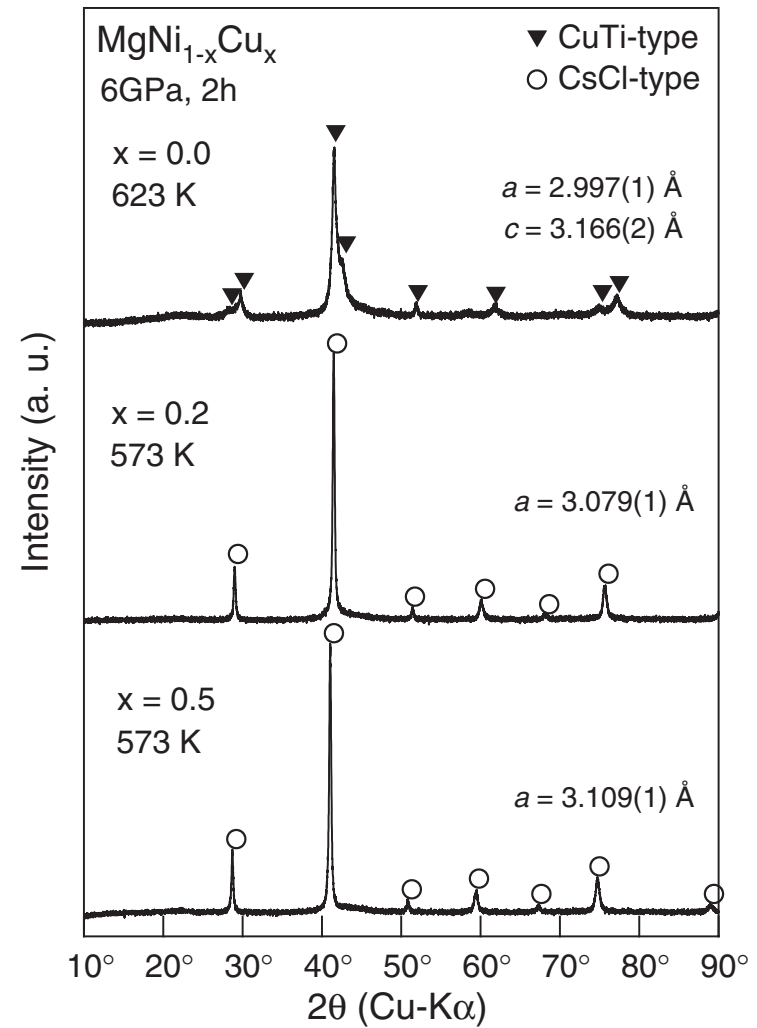

Fig. 3 XRD patterns of $\mathrm{MgNi}_{1-x} \mathrm{Cu}_{x}(x=0.0,0.2,0.5)$ prepared at $623 \mathrm{~K}$ or $573 \mathrm{~K}$ for $2 \mathrm{~h}$ under $6 \mathrm{GPa}$.

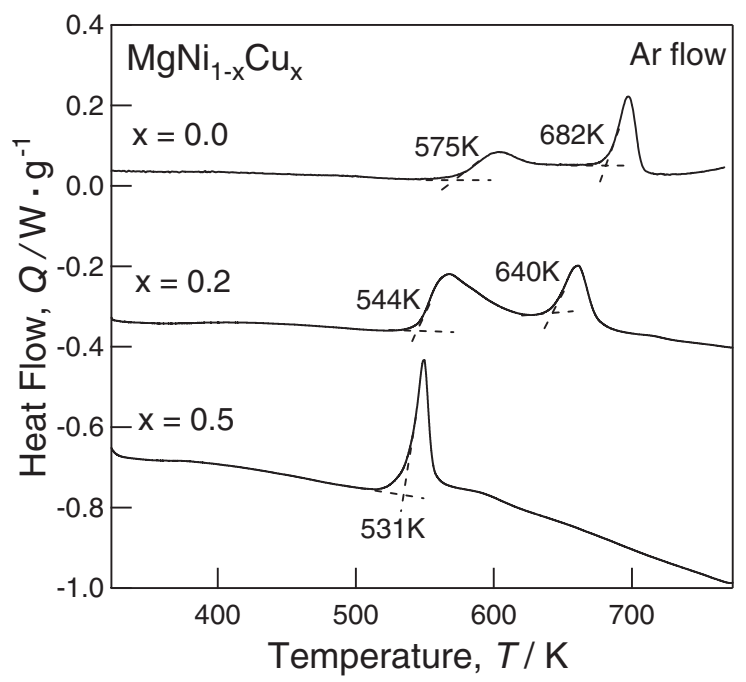

Fig. 4 DSC curves of $\mathrm{MgNi}_{1-x} \mathrm{Cu}_{x}(x=0.0,0.2,0.5)$ synthesized by highpressure under an Ar atmosphere.

performed under $2 \mathrm{MPa}$ of hydrogen atmosphere. Figure 5 shows DSC curves of $\mathrm{MgNi}_{1-x} \mathrm{Cu}_{x}(x=0.0,0.2,0.5)$ under hydrogen pressure of $2 \mathrm{MPa}$. An exothermic peak was observed for each sample. Our previous study showed that the exothermic reaction was a hydrogenation reaction. ${ }^{22)}$ The hydrogenation temperature and total peak area of exothermic curve of $\mathrm{MgNi}_{1-x} \mathrm{Cu}_{x} \quad(x=0.0,0.2,0.5)$ decreased with increasing of $\mathrm{Cu}$ content. Figure 6 shows XRD patterns of $\mathrm{MgNi}_{0.8} \mathrm{Cu}_{0.2}$ before and after DSC measurement. The metal sub-lattice of $\mathrm{MgNi}_{0.8} \mathrm{Cu}_{0.2}$ sample after hydrogenation

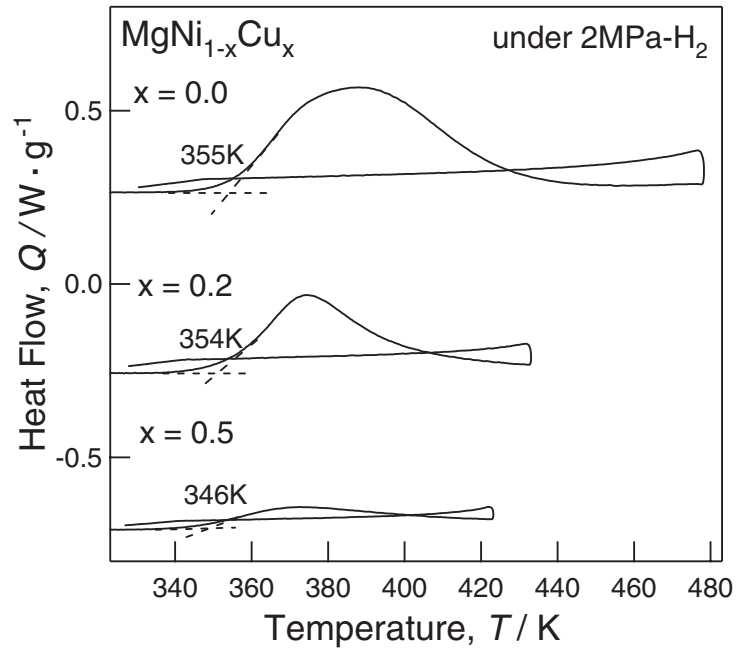

Fig. 5 DSC curves of $\mathrm{MgNi}_{1-x} \mathrm{Cu}_{x}(x=0.0,0.2,0.5)$ synthesized by highpressure under hydrogen pressure of $2 \mathrm{MPa}$.

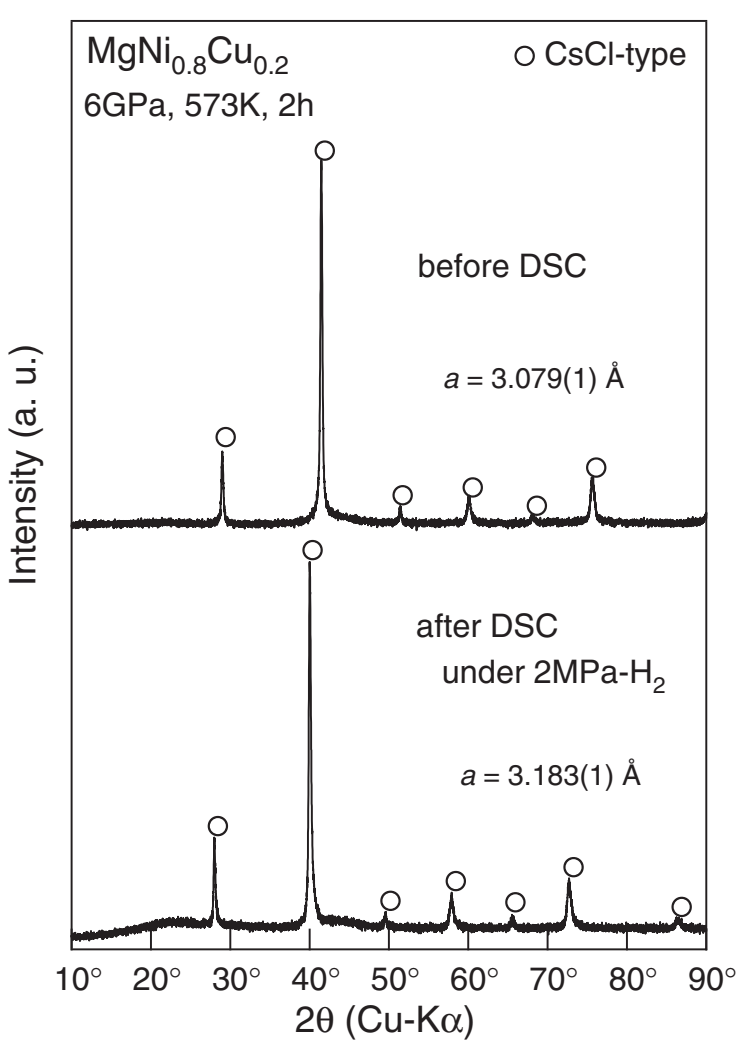

Fig. $6 \mathrm{XRD}$ patterns of $\mathrm{MgNi}_{0.8} \mathrm{Cu}_{0.2}$ before and after DSC measurement under hydrogen pressure of $2 \mathrm{MPa}$.

maintained CsCl-type structure and the lattice parameter of which expanded by $3.3 \%$. The behavior of $\mathrm{MgNi}_{0.5} \mathrm{Cu}_{0.5}$ was similar to that of $\mathrm{MgNi}_{0.8} \mathrm{Cu}_{0.2}$.

Figure 7 shows TDMS and TG profiles of hydrogenated $\mathrm{MgNi}_{1-x} \mathrm{Cu}_{x}(x=0.0,0.2,0.5)$. The hydrogen content of these hydrides were measured by TG. The hydrogen desorption temperature of $\mathrm{MgNi}_{1-x} \mathrm{Cu}_{x}(x=0.0,0.2,0.5)$ decreased with increasing of $\mathrm{Cu}$ content and the hydrogen content of these samples decreased with increasing of $\mathrm{Cu}$ content too. 


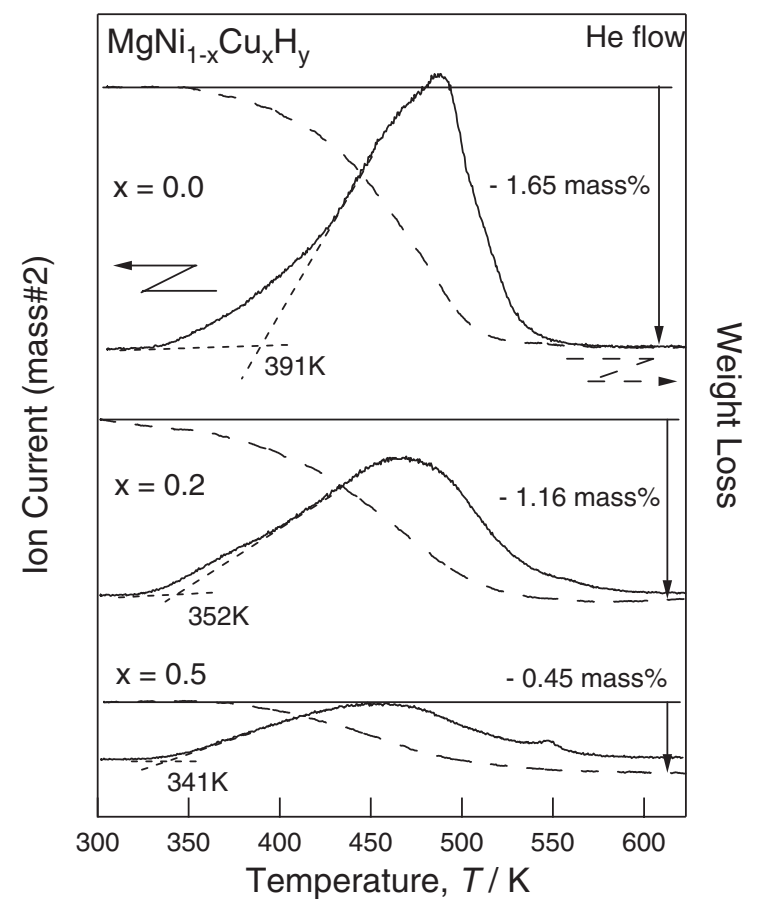

Fig. 7 TDMS and TG profiles of hydrogenated $\mathrm{MgNi}_{1-x} \mathrm{Cu}_{x} \quad(x=$ $0.0,0.2,0.5)$.

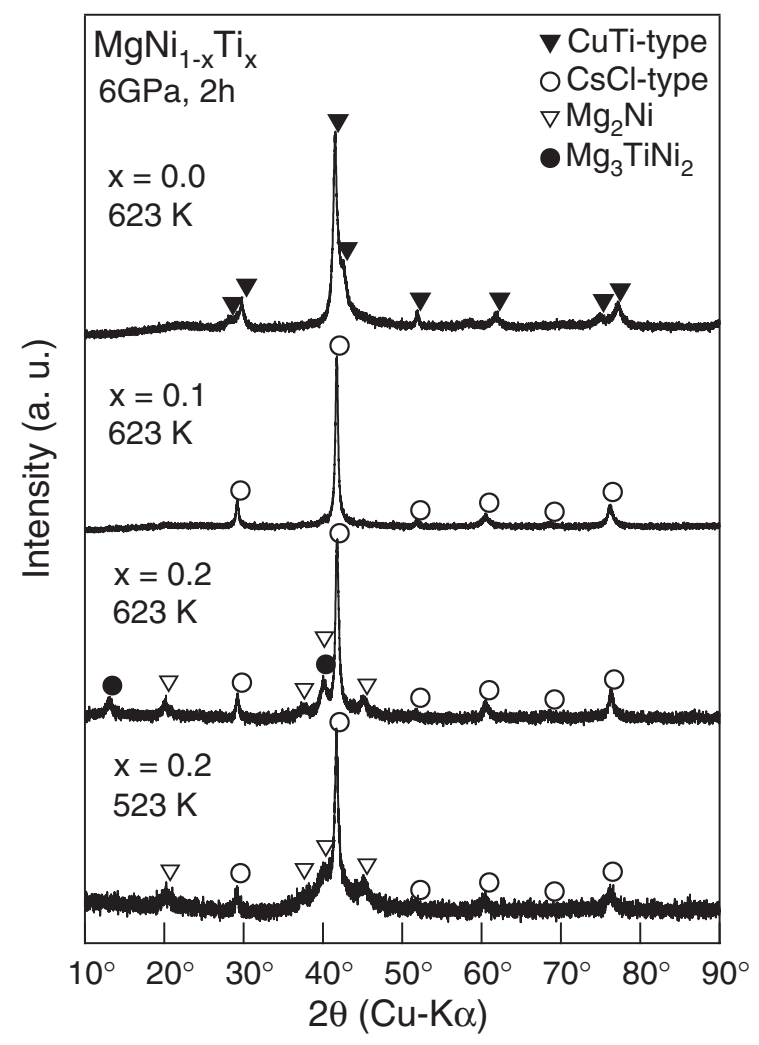

Fig. 8 XRD patterns of $\mathrm{MgNi}_{1-x} \mathrm{Ti}_{x}(x=0.0,0.1,0.2)$ prepared at $623 \mathrm{~K}$ or $523 \mathrm{~K}$ for $2 \mathrm{~h}$ under $6 \mathrm{GPa}$.

Figure 8 shows XRD patterns of $\mathrm{MgNi}_{1-x} \mathrm{Ti}_{x} \quad(x=$ $0.0,0.1,0.2)$ prepared from amorphous precursors at $623 \mathrm{~K}$ or $523 \mathrm{~K}$ for $2 \mathrm{~h}$ under $6 \mathrm{GPa}$. The $\mathrm{MgNi}_{0.9} \mathrm{Ti}_{0.1}$ was obtained as a single phase of CsCl-type structure. However, the sample

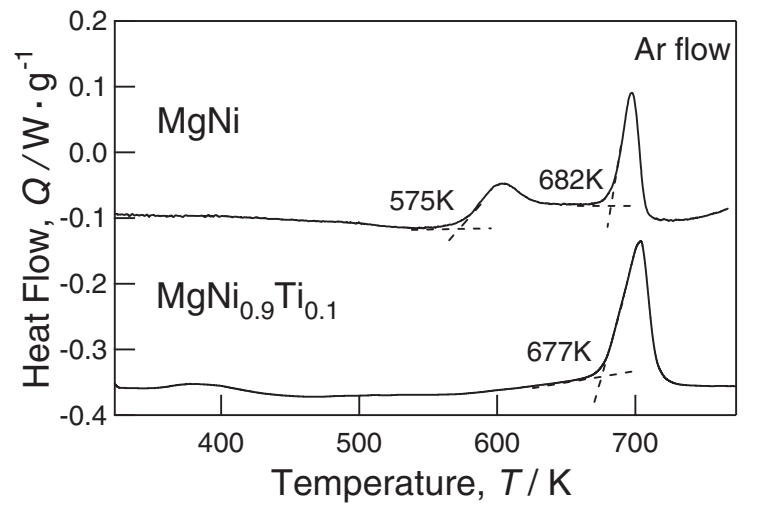

Fig. 9 DSC curves of $\mathrm{MgNi}$ and $\mathrm{MgNi}_{0.9} \mathrm{Ti}_{0.1}$ synthesized by highpressure under an Ar atmosphere.

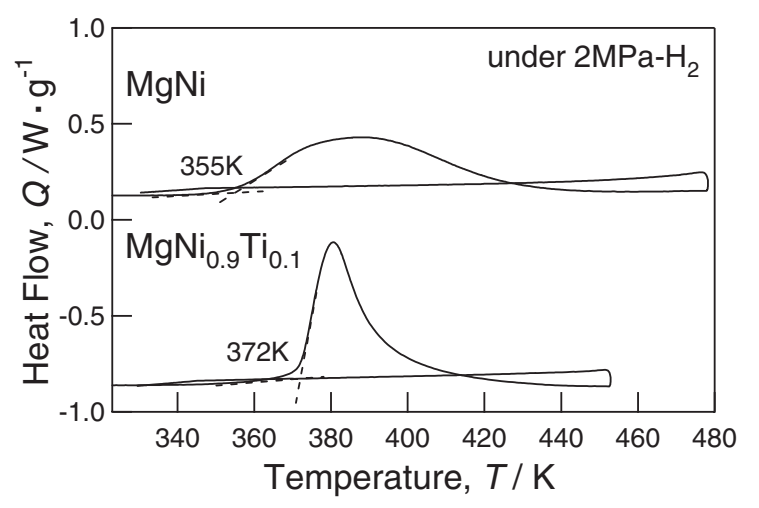

Fig. 10 DSC curves of $\mathrm{MgNi}$ and $\mathrm{MgNi}_{0.9} \mathrm{Ti}_{0.1}$ synthesized by highpressure under hydrogen pressure of $2 \mathrm{MPa}$.

prepared from amorphous $\mathrm{MgNi}_{0.8} \mathrm{Ti}_{0.2}$ was consisted of $\mathrm{Mg}_{2} \mathrm{Ni}, \mathrm{Mg}_{3} \mathrm{TiNi}_{2}$ phase besides CsCl-type phase.

Figure 9 shows DSC curves of $\mathrm{MgNi}$ and $\mathrm{MgNi}_{0.9} \mathrm{Ti}_{0.1}$. The decomposition of $\mathrm{MgNi}$ was two-step reaction at a temperature of up to $773 \mathrm{~K}$. On the other hand, $\mathrm{MgNi}_{0.9} \mathrm{Ti}_{0.1}$ decomposed into $\mathrm{Mg}_{2} \mathrm{Ni}$ type phase and $\mathrm{MgNi}_{2}$ type phase with one-step reaction with onset temperature of $677 \mathrm{~K}$. So it could be said that the decomposition temperature of highpressure phase increased with Ti substitution.

Figure 10 shows DSC curves of $\mathrm{MgNi}$ and $\mathrm{MgNi}_{0.9} \mathrm{Ti}_{0.1}$ under hydrogen pressure of $2 \mathrm{MPa}$. The onset temperature of hydrogenation of $\mathrm{MgNi}_{0.9} \mathrm{Ti}_{0.1}$ is higher than that of $\mathrm{MgNi}$. Figure 11 shows the XRD patterns of $\mathrm{MgNi}_{0.9} \mathrm{Ti}_{0.1}$ before and after DSC measurement. After hydrogenation, the $\mathrm{MgNi}_{0.9} \mathrm{Ti}_{0.1}$ maintained CsCl-type structure and the lattice parameter of which expanded by $4.8 \%$.

Figure 12 shows TDMS and TG profiles of hydrogenated $\mathrm{MgNi}$ and hydrogenated $\mathrm{MgNi}_{0.9} \mathrm{Ti}_{0.1}$. The substitution of $\mathrm{Ni}$ by $\mathrm{Ti}$ in $\mathrm{MgNi}$ decreased onset temperature of hydrogen desorption and improved hydrogen desorption amount from 1.65 mass \% $(\mathrm{H} / \mathrm{M}=0.68)$ to 2.06 mass $\%(\mathrm{H} / \mathrm{M}=0.84)$.

\section{Conclusion}

High-pressure synthesized MgNi with CuTi-type crystal structure absorbed and desorbed hydrogen reversibly at $473 \mathrm{~K}$ although it was not reported whether amorphous $\mathrm{MgNi}$ 


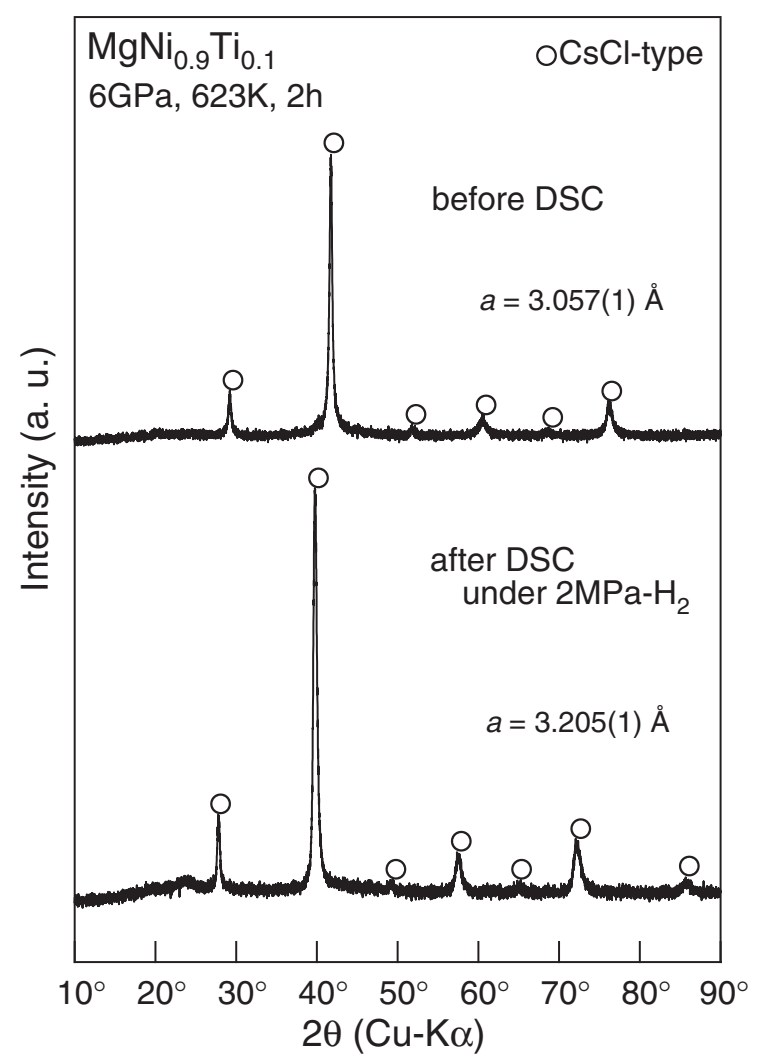

Fig. 11 XRD patterns of $\mathrm{MgNi}_{0.9} \mathrm{Ti}_{0.1}$ before and after DSC measurement under $2 \mathrm{MPa}$ hydrogen.

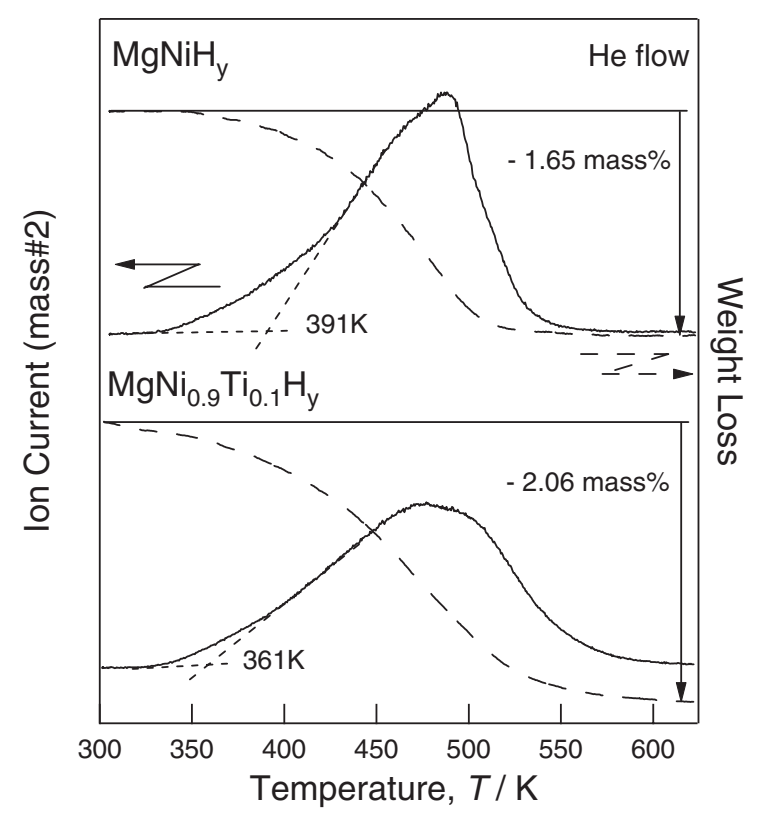

Fig. 12 TDMS and TG profiles of hydrogenated $\mathrm{MgNi}$ and $\mathrm{MgNi}_{0.9} \mathrm{Ti}_{0.1}$.

absorbed and desorbed hydrogen reversibly. The MgNi with CuTi-type crystal structure absorbed 2.75 mass $\%(\mathrm{H} / \mathrm{M}=$ 1.13 ) of hydrogen at $448 \mathrm{~K}$ at hydrogen pressure of $10 \mathrm{MPa}$. The crystal structure of $\mathrm{MgNi}_{1-x} \mathrm{Cu}_{x}(x=0.2,0.5)$ and $\mathrm{MgNi}_{0.9} \mathrm{Ti}_{0.1}$ were CsCl-type structure. These compounds were hydrogenated under hydrogen pressure of $2 \mathrm{MPa}$ and the crystal structures of these hydrides were CsCl-type structures in metal sub-lattice. The decomposition temperature, hydrogenation temperature and hydrogen desorption temperature of $\mathrm{MgNi}_{1-x} \mathrm{Cu}_{x}(x=0.0,0.2,0.5)$ decreased with increasing of $\mathrm{Cu}$ content. The decomposition temperature and hydrogenation temperature of $\mathrm{MgNi}_{0.9} \mathrm{Ti}_{0.1}$ was higher than that of $\mathrm{MgNi}$. The substitution of $\mathrm{Ni}$ by $\mathrm{Ti}$ in $\mathrm{MgNi}$ decreased hydrogen desorption temperature and improved the hydrogen desorption capacity from 1.65 to 2.06 mass $\%$.

\section{Acknowledgement}

This work has been supported in part by New Energy and Industrial Technology Development Organization (NEDO).

\section{REFERENCES}

1) B. Bertheville, P. Fischer and K. Yvon: J. Alloy. Compd. 330-332 (2002) 152-156.

2) F. Gingl, K. Yvon, T. Vogt and A. Hewat: J. Alloy. Compd. 253-254 (1999) 125-129.

3) M. Bortz, B. Bertheville, K. Yvon, E. A. Movlaev, V. N. Verbetsky and F. Fauth: J. Alloy. Compd. 279 (1998) L8-L10.

4) B. Bertheville and K. Yvon: J. Alloy. Compd. 288 (1999) 197-199.

5) H. Kakuta, A. Kamegawa, H. Takamura and M. Okada: Mater. Sci. Forum 350-351 (2000) 329-332.

6) H. Takamura, H. Kakuta, A. Kamegawa and M. Okada: J. Alloy. Compd. 330-332 (2002) 157-161.

7) Y. Goto, H. Kakuta, A. Kamegawa, H. Takamura and M. Okada: Sci. Technol. Adv. Mater. 4 (2003) 333-338.

8) Y. Goto, A. Kamegawa, H. Takamura and M. Okada: Mater. Trans. 43 (2002) 2717-2720.

9) H. Takamura, Y. Goto, A. Kamegawa and M. Okada: Mater. Trans. 44 (2003) 583-588.

10) H. Takamura, Y. Goto, A. Kamegawa and M. Okada: Mater. Sci. Forum 419-422 (2003) 983-988.

11) Y. Goto, H. Kakuta, A. Kamegawa, H. Takamura and M. Okada: Mater. Sci. Forum 475-479 (2005) 2521-2526.

12) M. Okada, Y. Goto, R. Kataoka, Y. Yambe, A. Kamegawa and H. Takamura: J. Alloy. Compd. 446-447 (2007) 6-10.

13) Y. Goto, T. Hayashi, R. Kataoka, H. Kakuta, A. Kamegawa, H. Takamura and M. Okada: Mater. Trans. 46 (2005) 1798-1801.

14) R. Kataoka, Y. Goto, A. Kamegawa, H. Takamura and M. Okada: Mater. Trans. 47 (2006) 1957-1960.

15) R. Kataoka, Y. Goto, A. Kamegawa, H. Takamura and M. Okada: J. Alloy. Compd. 446-447 (2007) 142-146.

16) Y. Goto, H. Kakuta, A. Kamegawa, H. Takamura and M. Okada: J. Alloy. Compd. 404-406 (2005) 448-452.

17) H. Watanabe, Y. Goto, H. Kakuta, A. Kamegawa and M. Okada: Mater. Trans. 45 (2004) 1350-1354.

18) H. Kakuta: Ph. D. thesis, Tohoku University, 2000 (in Japanese).

19) J. J. Reilly and R. H. Wiswall, Jr.: Inorg. Chem. 7 (1968) 2254-2256.

20) A. A. Nayeb-Hashemi and J. B. Clark: Binary Alloy Phase Diagrams, 2nd edn., ed. by T. B. Massalski (ASM International, USA 1991) p. 2530.

21) S. Orimo, H. Fuji, K. Ikeda, Y. Fujisaki and Y. Kitano: J. Alloy. Compd. 253-254 (1997) 94-97.

22) Y. Kamata, R. Kataoka, D. Kyoi, A. Kamegawa and M. Okada: Mater. Trans. 49 (2008) 457-460.

23) Y. Takaki, T. Taniguchi and K. Hori: J. Ceram. Soc. Jpn. Inter. Ed. 101 (1993) 373.

24) S. Orimo and H. Fujii: Appl. Phys. A 72 (2001) 167-186. 